\title{
Modulating troubles affiliating in initial interactions
}

\section{The role of remedial accounts}

\author{
Natalie Flint, Michael Haugh and Andrew John Merrison \\ Ulster University $\mid$ The University of Queensland $\mid$ York St John \\ University
}

Much of the research on affiliation to date has focused on how people do (dis)affiliation. This paper explores the remedial work that follows instances of disaffiliation between interactants who are getting acquainted. Building on an interactional pragmatics analytical approach informed by methods and research in conversation analysis, findings indicate that extended remedial accounts recurrently follow moments of disaffiliation in initial interactions. These remedial accounts enable participants to reposition a prior disaffiliative stance as (ostensibly) affiliative. It appears in initial interactions, then, that remedial accounts play an important role in modulating troubles in affiliating. We propose that the considerable interactional work undertaken by these participants to modulate such troubles reflects a general preference for agreeability in initial interactions, at least amongst (Australian and British) speakers of English.

Keywords: getting acquainted, disaffiliation, accounts, facework, conversation analysis, interactional pragmatics

\section{Introduction}

When meeting someone for the first time, a prosocial orientation on the part of participants is often expected, especially if those participants are orienting to the potential for an ongoing relationship to emerge from that initial encounter. This prosocial orientation involves the interactional accomplishment of actions that are broadly supportive of social solidarity - what Heritage (1984) has termed 'affiliation'. The notion of affiliation has also been used more specifically by some conversation analysts to refer to actions that are supportive of the affective stances enacted through prior turns (e.g. Jefferson, Sacks and Schegloff 1987; Jefferson 
1988). One of the aims of this paper is thus to discuss the different ways in which the term 'affiliation' has been used, and, building on that discussion, to propose that it be reserved for referring to cases involving affective stance in order to distinguish it from the related notion of 'agreement'. A second aim is to build on the body of work focused on how people do (dis)affiliation (e.g. Antaki 2012; Clayman 1992; Clift 2016; Lindström and Sorjonen 2013; Stivers 2008) by investigating the interactional work that follows instances of disaffiliation. Using an interactional pragmatics approach informed by methods and research in conversation analysis (CA), we analyse how remedial accounts (Goffman 1971) following instances of disaffiliation in initial interactions proffer opportunities to display agreement (with that account), as well as subsequent modulations of the initial affective stance that occasioned the disaffiliative response. A third aim is to offer further empirical support for claims that there is a preference for accomplishing 'agreeability' in initial interactions (Haugh 2015), for example, by minimizing or mitigating potential or emergent disagreements through subsequently accomplishing (partial) agreement on some aspect of that prior disagreeable. ${ }^{1}$ While previous research (e.g. Stokoe 2010) has investigated initial interactions in speeddating settings, this study also adds to the growing body of literature analysing how participants get acquainted in 'ordinary', non-romantic settings (Svennevig 1999, 2014; Haugh 2011; Haugh and Carbaugh 2015; Pillet-Shore 2010, 2011). More specifically, we examine the ways in which instances of disaffiliation are recurrently followed by remedial accounts in initial interactions amongst British and Australian speakers of English, and suggest that remedial accounts reflect this preference for 'agreeability' in first encounters. ${ }^{2}$

We begin with a brief overview of prior work on initial interactions. Next, we address terminology relating to affiliation, highlighting distinctions that have been made previously between agreement, alignment and affiliation, and the further distinction that can be drawn between disaffiliation and nonaffiliation. Thereafter, we briefly outline prior studies of remedial work and accounts (including 'justifying-accounts'). We next discuss the method by which our data was collected, followed by a brief discussion of our analytical approach. We then analyse the remedial accounts that follow instances of disaffiliation in initial interactions

1. This preference for agreeability thus concerns sequences of actions rather than the just-prior turn. It is related to, but not synonymous with the preference of agreement posited with respect to responses to questions (Sacks 1987), and assessments (Pomerantz 1984).

2. While our dataset is built from interactions in Britain and Australia, any issues relating to these varieties of English, qua varieties of English, are treated as lying outwith the scope of this paper. 
amongst our Australian and British participants. We conclude by considering implications of this line of research for the field.

\section{Background}

\subsection{Initial interactions ${ }^{3}$}

Much of the work on initial interactions has been undertaken in sociology and social psychology where researchers favour the use of questionnaires and surveys. There are, however, a growing number of studies grounded in the actual details of initial talk-in-interaction. Such studies have explored how newcomers are introduced (Pillet-Shore 2010, 2011), the ways in which self-presentation is sequentially accomplished through presentation-eliciting questions (Maynard and Zimmerman 1984; Svennevig 2014), (un)prompted self-disclosures (Haugh and Carbaugh 2015; Stokoe 2010), the role of jocular mockery and teasing (Haugh 2011, 2017a; Haugh and Pillet-Shore 2018), managing offence (Haugh 2015; Mitchell and Haugh 2015), and interpersonal dimensions of initial interactions more generally (McLaughlin, Cody and Rosenstein 1983; Svennevig 1999).

One finding to have emerged from this work is that participants in initial encounters, similar to talk-in-interaction in other mundane settings (Pomerantz 1984; Sacks 1987), may undertake considerable interactional work in order to seek agreement and avoid/minimise disagreement (Mitchell and Haugh 2015; Schneider 1988; Svennevig 1999). Haugh (2015,38) goes further, however, in beginning to suggest that this reflects "an ongoing orientation to interactionally accomplishing 'agreeability"' in initial interactions, which thereby enables participants to establish "some degree of familiarity, solidarity and affection" with one another (Svennevig 2014,322). However, this observed preference for agreeability in initial interactions raises the question of what happens when one or more participants offer responses that are not affiliative - that is, responses that display a different or opposing affective stance to that displayed by the prior speaker. McLaughlin, Cody and Rosenstein in early work on initial encounters suggested that "speakers initiate reproaches in order to elicit accounts which will provide a basis for reinterpreting disagreeables" $(1983,107)$. However, they did not examine in detail the

3. The term 'initial interaction' and the activity of 'getting acquainted' are often used interchangeably (Joyce 2015). Although we would argue that people in social relationships continue to get acquainted with one another outwith their first encounter, in this paper, we focus on the activity of getting acquainted in first encounters only. 
interactional mechanics by which these accounts arise. In order to explore this further, we now move to consider the literature on (dis)affiliation in more detail.

\section{2 (Dis)Affiliation}

Here we explore the various kinds of 'affiliative work' undertaken by participants. We discuss three key notions: affiliation, disaffliation, and nonaffiliation. Within this paper our focus will largely be on disaffiliation, with a brief exploration of nonaffiliation. These definitions will be explored with respect to their relationship with agreement, alignment and stancetaking.

\subsubsection{Affiliation, agreement and alignment}

The term affiliation is broadly used to refer to actions that are "supportive of social solidarity" (Heritage 1984, 269), most commonly with respect to the action preference of the sequentially prior action (Stivers, Mondada and Steensig 2011,21), but also with respect to those actions that display empathy or are supportive of an affective stance displayed by the prior speaker (Lindström and Sorjonen 2013,351; Stivers 2008,35-36). In this paper, however, we are concerned with affiliation at the affective level, namely, responses displaying support for the affective stance expressed by the prior speaker. ${ }^{4}$

Our notion of affiliation builds on the notion of 'stance'. Stancetaking has been described by many as being fundamental to human interaction (Du Bois 2007; Du Bois and Kärkkäinen 2012; Englebretson 2007; Goodwin 2007; Goodwin and Goodwin 1992; Iwasaki 2015; Ochs 1996), yet the concept is sometimes used in subtly different (and thus, potentially confusing) ways. Ochs $(1996,410)$, for instance, defines affective stance as "a mood, attitude, feeling and disposition, as well as degrees of emotional intensity vis-à-vis some focus of concern". We argue, however, that an affective stance is not a putative psychological state, but an action by which an interactant displays a particular attitude or feeling. As opposed to treating stance as being a 'mood' or a 'feeling', we treat stancetaking as something that can occur only through the back-and-forth of social interaction (Iwasaki 2015; Stivers 2008). It is worth briefly noting that stances themselves may vary in their degree of explicitness. In our current analysis, we therefore consider instances where affective stances are made either explicitly from the outset by the participant in question, or implied through other actions (such as self-disclosures) by participants about their personal habits or preferences.

4. Flint (2018) offers an even more nuanced account of affiliation in suggesting that it can be broken into further components. 
The preference for displaying agreement and avoiding or minimising disagreement in interaction has also been noted with respect to both questions (Atkinson and Drew 1979, 154; Sacks 1987, 58), and assessments (Heritage 1984, 219; Pomerantz 1975, 66, 1984, 77). However, while the notions of affiliation and agreement sometimes appear to overlap (particularly in the case of assessments), there are, nevertheless, important differences between them: agreement concerns evaluative stances (e.g. assessments, criticisms, praise), while affiliation concerns affective stances (e.g. liking/disliking a stance object). In short, 'agreement' is not (and should not be confused as being) equivalent to 'affiliation'.

Where a first action of an assessment is oriented to with a subsequent action of an equivalent/matching second assessment, we call this 'agreement' (as it is standardly referred to in CA literature). In terms of stances, we recognise that 'assessment' is essentially synonymous with evaluative stance. Hence when two evaluative stances are equivalent/matching, the term we adopt is, likewise, 'agreement'. The following extract (taken from Pomerantz 1984, 60) demonstrates what we are referring to as 'agreement':

\section{Agreement}

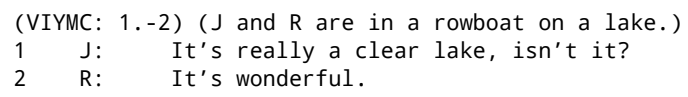

The terminological distinction that we wish to advocate in this paper is, however, that when a first affective stance is equivalent to / matching a second affective stance, the term that should be adopted is not 'agreement' but rather, 'affiliation'. The following extract (simplified from Flint 2018,50) shows two matching affective stances (both loving tea) and thus demonstrates what we are referring to as 'affiliation':

\section{Affiliation}

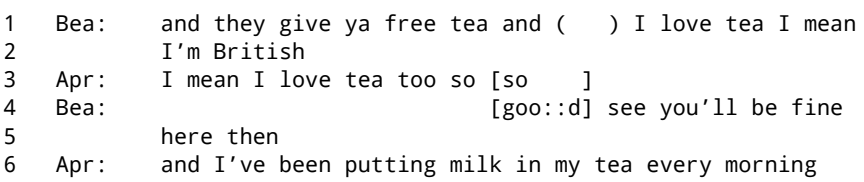

While agreement and affiliation are clearly related in terms of second actions matching first actions, we argue that maintaining this terminological distinction can only help in clarifying what is currently, at best, often potentially confusing and less than helpful usage. ${ }^{5}$ In other words, interactants cannot agree with

5. One reviewer raised the issue that distinguishing between an affective and an evaluative stance is not always straightforward. We completely agree and elsewhere, Flint (2018) discusses the nature of affective stances emerging out of other actions including evaluative stances. For 
affective stances, but they can affiliate with them. It is crucial for participants (and thus analysts) to recognise these different types of stances as they arise in interaction in order to fit responses that are either affiliative or agreeing (or in some cases both). For example, it has been observed that affiliative responses from recipients are preferred following the display of an affective stance by the speaker in storytelling sequences (Lindström and Sorjonen 2013; Stivers 2008).

Finally, we follow Stivers (2008) in distinguishing between affiliative and aligning responses. Aligning actions are those that orient to and further the progressivity of an ongoing social action (Stivers 2008), including accepting its presuppositions and terms, matching its formal design preference by producing a type-conforming response (Stivers et al. 2011,20), and accepting the interactional roles involved in the ongoing activity (Stivers 2008,31). In short, the distinction between alignment and affiliation can be described as involving two different levels of cooperation between participants: to align is to cooperate at a structural level (cf. Asmuß 2011; Keevallik 2011), whereas to affiliate is to cooperate at an affective level (Stivers et al. 2011). It is also worth noting that aligning responses do not necessarily have to go hand-in-hand with affiliative ones - dispreferred, disaffiliative next turns can still be type-conforming possibilities for an aligning next action. ${ }^{6}$

\subsubsection{Disaffiliation and nonaffiliation}

Disaffiliation involves rejection of a prior affective stance. Here, the prior affective stance implemented through a prior speaker's turn is neither accepted nor supported by the other participant(s) in the interaction. In addition, disaffiliative responses must also demonstrate some kind of opposition to the prior affective stance. Cases where there is no display of acceptance or support of a prior affective stance, and also no display of an opposing stance, we refer to as 'nonaffiliation' (cf. Holt 2012). In other words, rather than actively displaying an opposing stance (which would be disaffiliative), a nonaffiliative response constitutes a potential "noticeable absence" (Sacks 1995; Schegloff 1968), where an affiliative response is withheld despite being invited through the display of a particular affective stance

the purposes of the current paper, however, we are simply proposing that the term 'affiliation' be reserved only for use in relation to affect, and that while evaluative and affective stances are sometimes displayed through the same action, participants nevertheless may place particular import on one or the other at times.

6. When (dis)affiliating, interactants produce a type-conforming response which aligns specifically with the stancetaking action as opposed to aligning with any other ongoing action (such as storytelling). Therefore affiliating (aligning with a stancetaking action) may require disaligning with some other action (e.g. halting the progressivity of a storytelling: cf. Stivers 2008; Stivers et al. 2011). 
in a prior turn (Stivers and Rossano 2010). We suggest that nonaffiliation can be accomplished in various ways, including through topic shifts (Jefferson 1993), or by speakers allowing conversation sequences to lapse through non-responsive gaps in talk (Stivers and Robinson 2006).

In the context of initial encounters, Svennevig $(1999,155)$ claims that agreeing and avoiding having different points of view does not make for very interesting conversation, and even suggests that differences in points of view amongst participants is a precondition for conversation to occur. He also states that disagreement (and consequently, we would add, disaffiliation) is more readily accepted in close or intimate relationships in which participants generally presume that the ongoing co-constitution of their relationship as intimate or close licenses some degree of disagreement. But when participants are getting acquainted in initial interactions, solidarity cannot be presumed, and it must therefore be interactionally accomplished. While in some contexts, disagreements may indeed index solidarity between participants, disagreements can only be used in this manner if participants presume their relationship is a sufficiently close or intimate one. This is less readily applicable in initial interactions - at least amongst our (Australian and British) speakers of English - as we will see in the following analysis, where it becomes apparent that the participants engage in considerable interactional work to modulate emergent disaffiliative and nonaffiliative responses through proffering accounts.

\subsection{Accounts and remedial work}

This section briefly introduces what Goffman (1971) termed 'remedial work', or what now generally falls under the study of 'accounts' in CA. Goffman (1971) defines the function of remedial work as changing the meaning of an act which may otherwise be seen as offensive into something which can be seen as acceptable. According to Goffman, there are typically three devices used to accomplish remedial work: accounts, apologies, and requests. In our data, however, we have observed only accounts, and thus our focus concerns only the use of accounting devices to modulate prior instances of disaffiliation.

Studies of accounts are not limited to Goffman's (1971) analyses of remedial work. Accounts have been studied across disciplines, including social psychology (Schönbach 1990; Semin and Manstead 1983), and CA (Antaki 1994; Heritage 1984). Systematic study of accounts in the CA literature can be traced back to Sacks' very first lecture of Fall 1964, in which he claimed, "Accounts are most extraordinary" (Sacks 1995, 4). An (explicit) account, in CA, involves an interactant providing explanatory talk to offer a reason that exonerates themselves from prior or current socially sanctionable behaviour (Antaki 1994; Heritage 1988). 
Scott and Lyman (1968) separate accounts into two subordinate categories: 'justifications' and 'excuses'. Justifications are generally defined as accounts where responsibility is accepted by the speaker, but a legitimate reason is offered to explain the circumstances of the action. Justifications thus differ from excuses in that the person in question accepts responsibility or blame for an action, whereas excuses typically deny any measure of responsibility. These have since been expanded with the addition of another two subordinate categories: 'concessions' and 'refusals' (Schönbach 1990). Despite these additions, it is the distinction between justifications and excuses which is generally treated as the most significant (e.g. Antaki 1994; Buttny 1993; Heritage 1988; Semin and Manstead 1983).

Another distinction which can be made between justifications and other forms of accounts includes the temporal positioning of the account in relation to the potentially offensive action (Heritage 1988). Justifications involve individuals managing their social breaches by accounting for their behaviour after the sanctionable act has occurred, and thus differ from accounts that precede actions which are referred to as 'disclaimers' or 'pretexts' (Nichols 1990). From a sequential perspective, justifications can be characterised as accounts which invariably follow a potentially offensive action. While justifications can occur later in the same interaction (or even in subsequent interactions), in this paper we investigate only cases where the justification is temporally situated immediately following instances of disaffiliation.

\subsection{Accounts and dispreferred responses}

Integral to the notion of preference in CA is the claim that dispreferred responses are recurrently accomplished as such through prefaces, delays, mitigations and accounts (Atkinson and Drew 1979,58-59; Heritage 1984,334-335; Levinson 1983, 266-267; Schegloff 2007). Yet as Heritage $(1984,269)$ notes, "the role of accounts in dispreferreds is complex". While accounts have been discussed in the context of dispreferred responses to invitations, offers or requests (Heritage 1984, 269-273), for instance, they have not been discussed in relation to disagreements (Kotthoff 1993; Pomerantz 1975, 1984). One question this raises, then, is on what occasions do accounts feature as a component of dispreferred responses? In the remainder of this paper we suggest that while they may not regularly occur in disagreements with prior assessments - or least they have not been observed to do so thus far by CA scholars - they can be observed to recurrently follow disaffiliative responses to the just-prior displayed affective stance of another participant 
in the context of initial interactions. ${ }^{7}$ This finding highlights the importance, we contend, of distinguishing between (dis)affiliation and (dis)agreement.

\section{Data and method}

\subsection{Data collection}

The data for this study comprise a subset of fifteen recordings of initial interactions between previously unacquainted individuals taken from a larger corpus of more than seventy five encounters amongst American, Australian (Haugh 2011; Haugh and Carbaugh 2015), and British (Flint 2016) speakers of English. The six British initial interactions were collected in York, UK in 2015-2016; the nine Australian interactions were collected in Brisbane, Australia in 2012-2013.

All of the participants volunteered to take part in the research and consented to having their conversations recorded, but were not informed of the purpose of the study beyond an initial brief that the study was about communication. During this initial briefing, it was explained that the interaction could be of any length and about any topic. Due to this deliberately vague briefing, the lengths of the interactions vary from 16 to 107 minutes. All interactions were both audio and video recorded. The participants were paired according to their availability. ${ }^{8}$

More than twenty instances in which disaffiliative responses followed the expression of an affective stance by another participant were identified for detailed analysis. This involved careful examination of their sequential organisation through repeated viewings of the interactions in question and detailed, iterative transcription. While each of these sequences was locally situated, and thus its development was contingent on the particularities of that particular interaction, they nevertheless exhibited a common sequential pattern that is described in $\$ 4$. Before moving to do so, however, we first briefly outline our overall analytical approach.

7. This is not to say that accounts do not occur subsequent to disaffiliative responses in other contexts, but this is an empirical question that lies outwith the scope of this paper.

8. The participants were all university students or graduates and were between the ages of $18-35$. A roughly even number of same and mixed gender dyads were recorded. We have not examined the potential effects of such variables in the course of our analysis, however, as our aim here is not to generalise to the entire population of Australian or British speakers of English. 


\subsection{Analytical framework}

The tools applied for both the design and the analysis of this project are informed by conversation analysis. CA as a method is not statistical nor motivational in its design. Instead, CA methods build on systematic investigations of the sequential patterns of talk-in-interaction. The focus of early work in CA was on the sequential structure of conversational talk, however, in recent years there has been a shift from exclusively studying the interactional machinery of talk to a broader study of the locally situated nature of talk and the (interpersonal) relationships accomplished therein. The latter is broadly consistent with interactional pragmatics (Arundale 2010; Haugh 2012), an approach which is informed by research and methods in CA, but which has an expanded focus on issues such as facework and $\mathrm{im} /$ politeness that have not (traditionally, at least), played a large role in CA (though cf. Lerner 1996; Schegloff 1988).

Arguably, a key advantage in using initial interactions as a resource for exploring talk-in-interaction is that the entirety of the social relationship (at the time of the recording) is on record. Because of this, we, as analysts, have access to the entire social relationship between participants, allowing for a better understanding of the way in which relationships are interactionally accomplished through talk. There may, of course, be elements of common ground that the participants can draw upon, however these tend to be related to local factors in the immediate environment and these are, for the most part, apparent in the recordings.

\section{Remedial accounts in initial interactions}

A key finding to emerge from our analysis of disaffiliation in these initial interactions was that these disaffiliative stances were invariably followed by extended account sequences. The participants in these initial interactions thus evidently oriented to disaffiliative stances as forms of interactional trouble requiring remedial work. In this section, we consider two extended extracts to illustrate this overall finding, and to closely examine the overall sequential structure of instances where troubles affiliating emerged, and how initial interactants remedy instances of disaffiliation through extended justification-accounts.

The overall sequential pattern that emerged across instances of disaffiliation sequences in our datasets involved three interlinked moves: 
1. a disaffiliative response (by second speaker) to a prior (first) speaker's stance

2. an (unprompted) extended justification-account

3. some form of stance movement on the part of the first speaker that enables them (ostensibly at least) to affiliate with the second speaker's (initially) disaffiliative stance.

The following analysis thus pays close attention to how interactants jointly remedy disaffiliations in these interactions. Specifically, we focus on each of these three moves. We draw attention to features that impact on the ways in which disaffiliations are remedied by interactants, including the occurrence of hearable gaps, marked facial expressions when delivering a disaffiliative turn, the use of repetition when accounting for a stance, and the use of extended accounts to justify potentially offensive actions. The interactional work that occurs both as the disaffiliative response itself is delivered, and in the accounts that arise subsequent to it, involves extended collaborative effort on the part of both participants oriented to remedying a prior moment of disaffiliation. We also draw attention to how the extended justification-accounts proffer opportunities for (partial) agreement between the participants thereby modulating the prior momentary disaffiliation. This analysis thus grounds our claim that the participants are indeed treating disaffiliative responses as interactional troubles that require remedial work.

We begin our discussion with an extract from an initial interaction between two British university students, Becky and Laura (all names are pseudonyms). ${ }^{9}$ Prior to this extract, Becky has been talking about deleting accounts on social media and "disappearing from the internet", she then assesses this as "going overboard" prior to the but-prefaced next turn regarding the social media website, Reddit. As we shall see, this disaffiliation is immediately followed by an extended justification-account (hence the long extract).

Extract 1. HMHA: BritBrito4: 23:00

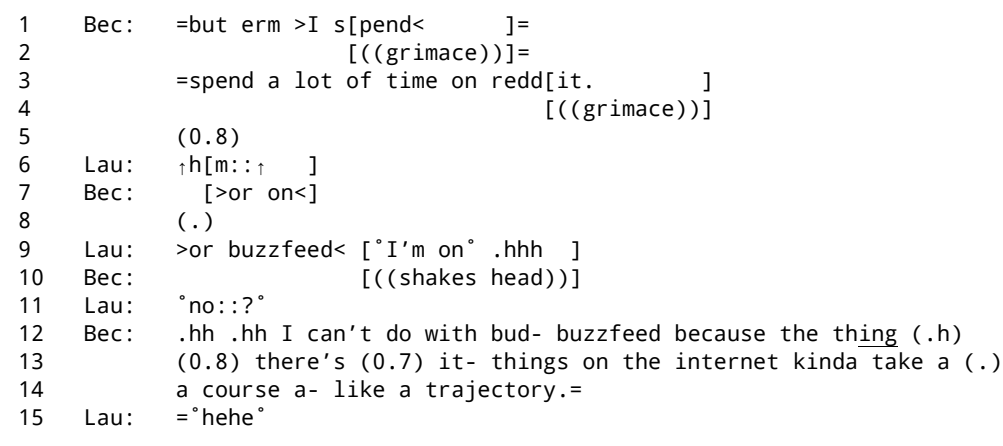

9. Standard CA transcription conventions have been used (Jefferson 2004) with additional conventions for other relevant non-verbal elements of the interaction. See Appendix for details. 


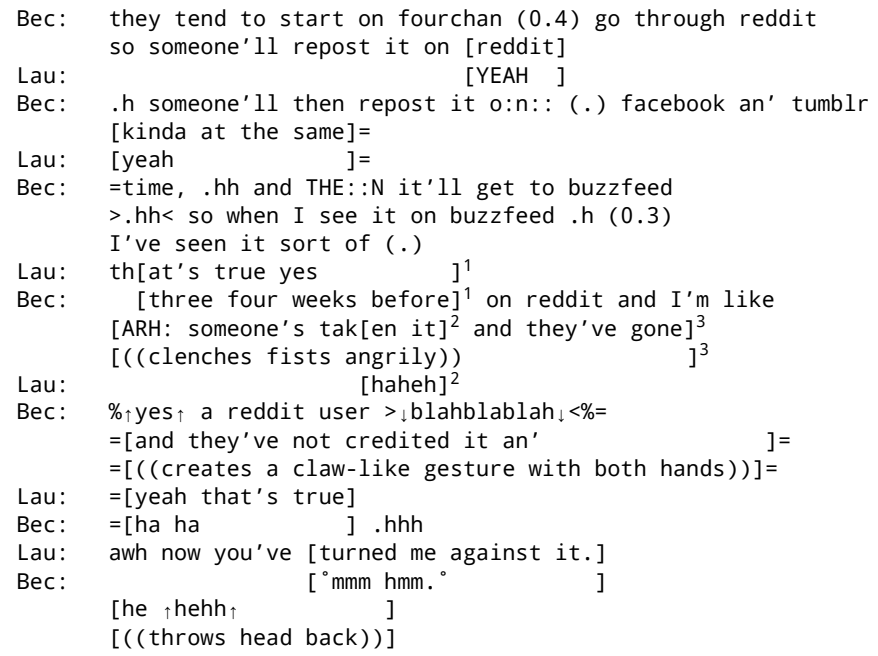

In line 1 , starting with a but-preface (which contrasts with the negative aspects of social networking that they have previously been discussing), Becky self-discloses about her habit of spending a lot of time on Reddit, grimacing as she does so. During this grimace, there is mutual gaze between Laura and Becky, and, as a result, this non-verbal behaviour is on record. Following this initial self-disclosure, at line 5 there is a significant gap of 0.8 seconds. This non-responsive gap in talk from Laura is indicative of nonaffiliation with Becky's stance towards Reddit. ${ }^{10}$ It becomes evident across the following turns that troubles in affiliating have started to emerge from this silence at line 5. At line 9, Laura proffers an anticipatory completion (Lerner 1991) of Becky's prior turn in line 7 (">or on<"). With it, Laura proposes Becky's overuse of social networking is not limited to Reddit but extends to Buzzfeed. While this anticipatory completion is nominally affiliative, as through it Laura claims she shares what she takes to be Becky's implied stance here (Hayashi 2013), it turns out to be nonaffiliative, as by affiliating with what she takes to be Becky's stance on over-use of social networking, Laura continues to avoid taking any stance on Reddit itself. Given Laura's initial silence in line 5 (which projects a disaffiliative response), through her non-committal continuer in line 6 and the offering of a candidate understanding of another social networking site in line 9, Laura, in effect, proffers a topic shift through stepwise transition (Jefferson 1984). This potential new topic is undoubtedly not random. We suggest that Laura offers the candidate of Buzzfeed as a possible completion to Becky's prior turn because it is this Social Networking Site that Laura has more experience with.

10. Although Becky claims to use social media too often, she nevertheless keeps using Reddit, thereby implying that she likes it too much to give up. 
Buzzfeed is a popular website that provides a wide range of populist content which is often circulated through other popular platforms such as Facebook and Twitter. It is a go-to site for many of the Millennial generation. Furthermore, based on this, Laura may assume that Becky (also a Millennial) is likely to interact with this site in a similar way - and if she does, then offering Buzzfeed as a possible stepwise topic shift would enable possibilities for future in-common and agreeable interaction. However, her candidate is dismissed by Becky followed by an account for her disaffiliation with Laura's candidate of Buzzfeed.

At this point, the first of the interlinked moves is explicitly accomplished as Becky disaffiliates with Laura's candidate completion, thereby dismissing Laura's presumption that Becky is a Buzzfeed user. Becky's disaffiliation with Laura's presumed stance with respect to Buzzfeed begins nonverbally with a headshake (line 10) prompting a display of a tentative understanding from Laura (in line 11) that Becky is rejecting her anticipatory completion, and, with that, Laura's proposed topic shift. In line 12 Becky makes it verbally explicit that she is rejecting Laura's candidate here. ${ }^{11}$ In so doing, Becky disaffiliates with Laura's move to affiliate with what the latter has presumed to have been the stance proffered by Becky in lines 1-4.

Notably, the initial nonverbal rejection of Laura's suggestion of Buzzfeed occurs before any verbalisation of this is offered, thereby allowing Laura an opportunity to reformulate her claim to lessen the potential degree of disaffiliation (Pomerantz 1984). Laura does this through the use of rising intonation at line 11

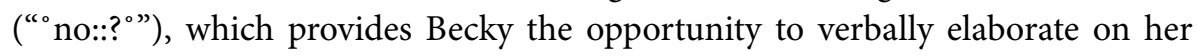
disaffiliative stance. She begins with an explicitly disaffiliative statement (line 12), followed by "because", projecting a forthcoming account for her disaffiliative response. Becky does not, however, make excuses for the disaffiliation. Instead she justifies her reasons for taking a disaffiliative stance. In terms of Goffman's (1971) description of accounts, Becky's justification can be understood as being an account which claims full responsibility for the potentially offensive act of disaffiliation and displays that the act was done with full awareness and competency. Yet despite this, Becky attempts to modulate the potential offense caused by the disaffiliative action.

Through the initiation of an unprompted justification (the second of the three moves recognised in the disaffiliation sequences), Becky subsequently employs a 'telling' to mitigate her prior disaffiliation. Specifically, through the employment of this device to justify her disaffiliation with Laura's prior attempt to affiliate, Becky establishes a performed narrative mode. The use of tellings to proffer accounts has

11. Laura orients to the sensitivity of this disaffiliative move by Becky in line 15 through sotto voce laughter. 
been recognised as a means for establishing rapport between the teller and their recipient (Goffman 1974, 503; Lerner 1992).

Semin and Manstead (1983) suggest that appealing to another's moral values is characteristic of justifications. Becky begins her justificatory account by appealing to moral values, as she claims that one of the reasons for her dislike of Buzzfeed is that their content is not original and can be found on various other websites first. Within this part of her account, there appear to be two factors which make Buzzfeed problematic for Becky. The first is that the content can be seen elsewhere sooner, and the second is that the content which is adapted from other social media platforms is not acknowledged as it should be, therefore appealing to moral values of giving due credit to content providers. Notably, the second part of the account appears to be more crucial to Becky, and it is as this point that her account appears to be accepted by Laura.

During this extended justification-account, Laura aligns with Becky's action using type-conforming minimal responses that are frequently placed in overlap with Becky's telling, including line 18 ("YEAH") and line 21 ("yeah"), as well as through laughter (line 29). Stivers (2008) has suggested that alignment produced towards the end of a story is indicative of an incipient display of an affiliative stance. Lerner (1992) has also noted that telling activities are sometimes treated as uninterruptable monologues, although the importance of recipients demonstrating their understanding and/or appreciation of a telling has also been noted due to the fundamentally collaborative nature of tellings (Lerner 1992; Sacks 1995). As the telling comes to a close, Laura's aligning responses also involve affiliating with Becky's initial stance (disliking Buzzfeed) through this telling, as seen at line 33 ("yeah that's true"), for instance.

As the justification is built up through a telling, it is unsurprising that it takes a significant amount of time to complete. Yet in observing the amount of interactional work invested in developing a justification to attempt to remedy the disaffiliation, it is evident that the disaffiliation was oriented to by the participants as an interactional trouble that warranted extensive remedial work. In other words, Becky's disaffiliative stance is oriented to as an interactional trouble that warrants halting the progressivity (Stivers and Robinson 2006) of the interaction for a significant amount of time in order to attend to the difficulties which the participants are evidently having in affiliating at this point in their ongoing interaction.

Finally, at line 35, Laura enacts a striking change in stance from a person who had introduced the topic of Buzzfeed (a topic in which she is invested) to a person who now (ostensibly) claims to have been turned against Buzzfeed. This ostensible 'stance movement' marks the third of the interlinked moves in disaffiliation sequences, and allows the talk to move away from the disaffiliative topic (Buzzfeed) and onto something new and more 'agreeable'. Through this shift in 
stance claimed by Laura, and the accompanying laughter from Becky, both participants are able to treat this prior disaffiliation as remedied and the interaction progresses. In sum, an initially disaffiliative action where Becky rejected Laura's attempt to affiliate through an anticipatory completion was oriented to by both participants as an interactional trouble that occasioned an extended account during the delivery of which Becky halted the progressivity of the interaction for a significant amount of time. In investing this amount of talk in modulating this momentary disaffiliation, the participants thereby oriented to troubles in affiliating as warranting an extended remedial account sequence.

The next extract we examine is taken from an initial interaction between two Australians. Norma and Toby have been engaged in a joint fantasising sequence in which they are bemoaning the ever-increasing regulation of credentials for seemingly straightforward occupations (Haugh 2017b,160-162). Toby has just jokingly proposed that soon people will need a "cert four ${ }^{12}$ to make a cup of coffee" (data not shown), which is subsequently exploited to manage a stepwise topic transition (Jefferson 1984) to the question of whether Toby prefers ${ }^{13}$ coffee or tea. Similar to Extract 1, there is an extended justification-account following a disaffiliation, however a significant difference between the extracts is that here there is no stance movement.

Extract 2. CAAT: AusAuso9: 13:05

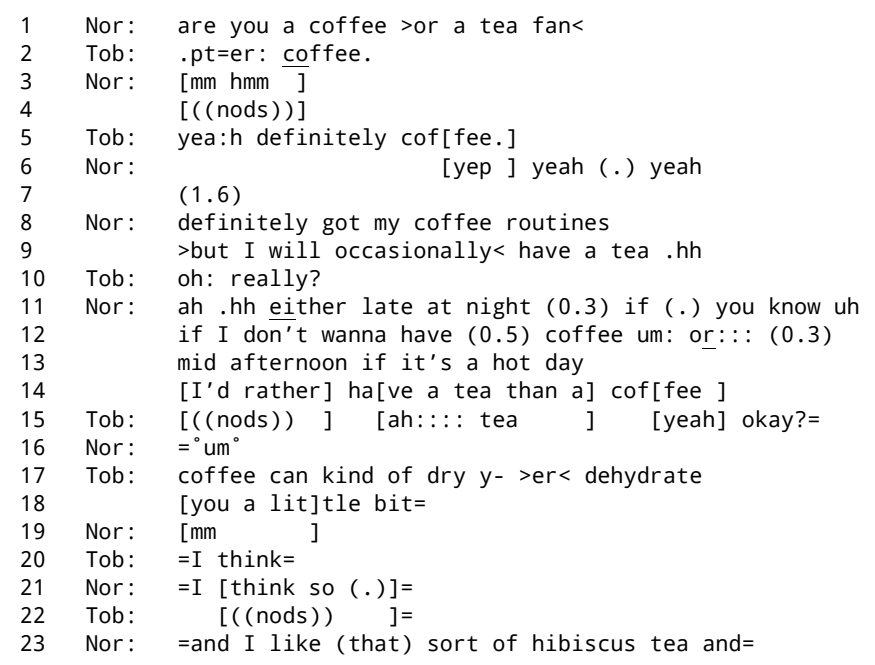

12. Cert four refers to "Certificate IV", a pre-diploma qualification awarded by non-university higher education providers in Australia for particular vocational skillsets.

13. In discussing affective stances, we sometimes talk of preference in a non-technical, non-CA sense. However, when we use the word 'prefer', the context should be sufficient to determine in what sense we are using it. 


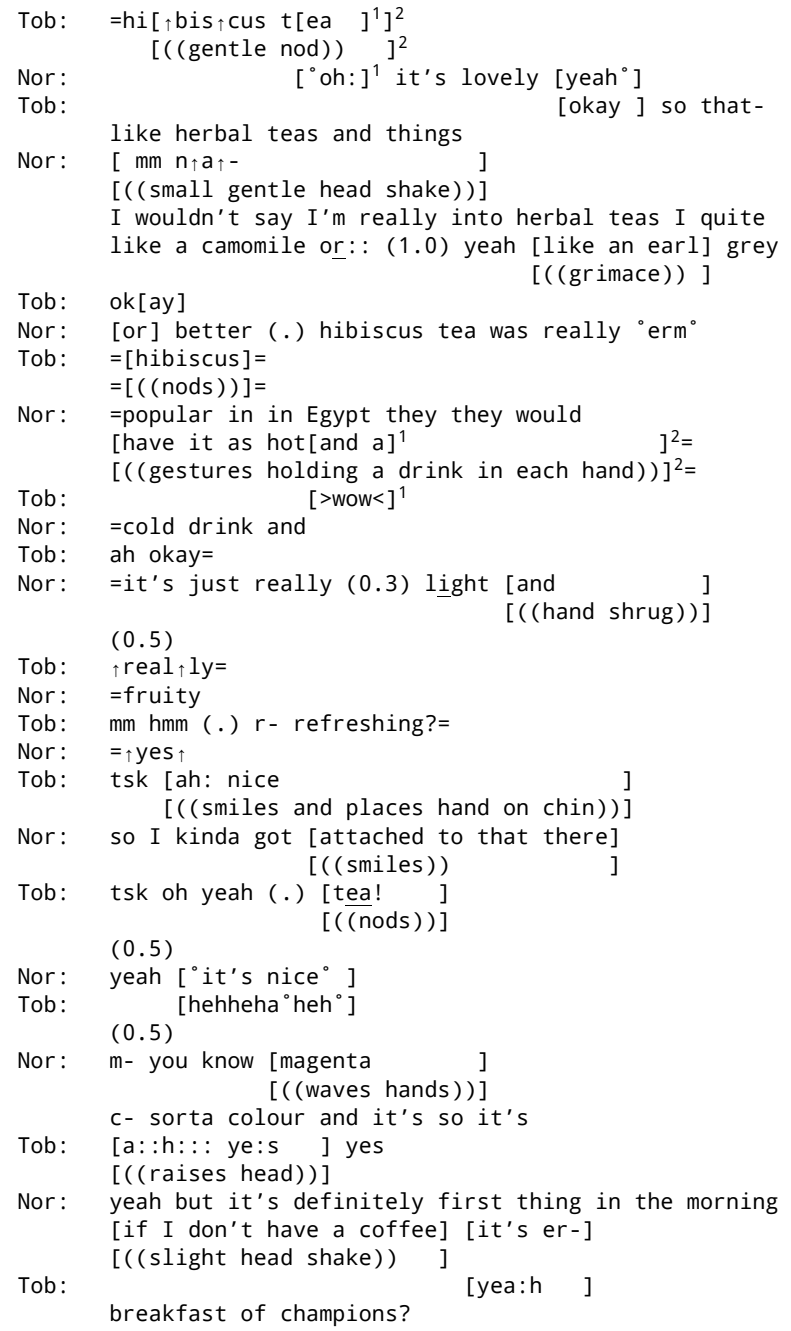

This extract begins with a presentation-eliciting question from Norma delivered through an alternative question format (line 1). Given this format is, in general, used much less frequently in seeking information (Stivers 2010, 2776), and the way in which the latter alternative is accomplished using a rush-through, the question appears to be designed to avoid the implication that coffee is the preferred candidate answer (Pomerantz 1988). Toby is thus being positioned to take a stance on which drink he prefers without Norma offering any indication of what her own stance might be. In this case, then, Toby is prompted by Norma to take an affective stance, but without knowing whether it will be affiliative or disaffiliative. Toby responds hesitantly at first, providing one of the two options suggested by Norma (line 2). Following an aligning, although not necessarily affiliative response from 
Norma at line 3, Toby upgrades and intensifies his stance at line 5, with the use of "definitely" suggesting that he is expecting Norma to strongly affiliate with this upgraded stance. However, a straightforwardly simple affiliative response from Norma is not forthcoming.

Norma builds what turns out to be a disaffiliative response in a way typical of those outlined within the literature on delivery of dispreferred responses (Atkinson and Drew 1979; Heritage 1984; Pomerantz 1984). She begins by initially agreeing (lines 6 and 8) before indicating a contrasting stance through but-prefacing a subsequent claim that she also drinks tea (line 9). This is an example of the phenomenon observed by Pomerantz $(1975,1984)$ in relation to disagreeing components being delayed within turns. This can be achieved through the use of silences or by building a turn as an "agreement-plus-disagreement" turn shape in Pomerantz' terms $(1984,72)$, which in this case also involves affiliation-plus-disaffiliation (Flint 2018). Pomerantz $(1984,74)$ also observes that the agreement components which preface disagreement are characteristically weak, and the same can be said of the affiliation-plus-disaffiliation turn shape observed in lines 8-9. (A delaying strategy can similarly be observed in Extract 1 (line 5) as the provision of a disaffiliative turn is delayed initially by a significant pause, and subsequently through the use of gesture, before a disaffiliative stance is delivered.) The stance is also mitigated as it is delivered as Norma states that she will ">occasionally $<$ have a tea" (line 9).

Following this disaffiliative response (the first of the three interlinked moves), Toby treats Norma's stance as somehow unexpected (line 10: "oh: really?"), thereby offering Norma an opportunity to provide an account, whilst also orienting to Norma's subsequent stance as one with which he cannot straightforwardly affiliate. Norma's account attempts to claim reduced responsibility for the disaffiliating action and to mitigate it, as she provides many reasons for why the act should not be viewed as troublesome. It is at this point that the second of the interlinked moves begins as Norma starts to provide a justification for disaffiliating with Toby's preference for coffee and with her own ostensible stance of having "coffee routines". Norma's justification is built through explaining the circumstances in which she drinks tea: she only drinks tea "late at night" or "if it's a hot day" (lines 11-14). This justification appears to orient to the possibility (as indicated by Toby's "oh: really?" at line 10) that her stance may have been inadvertently misrepresented as a clear overall preference for tea. This account seems to be accepted by Toby at line 15 through the use of gesture ("nods"), repetition ("ah:::: tea"), and a minimal acknowledging response token ("yeah"). This extract provides more evidence in support of Stivers' (2008) claim that nodding in a mid-telling position functions as an aligning response, but it is also indicative of implicit acceptance of the claim and incipient affiliation. Throughout the extract, there are many exam- 
ples of apparent acceptance of Norma's account by Toby, through aligning nods (lines 15, 22, 37), repetition of "tea" and "hibiscus" from the prior turn (lines 15, 24,36 ), and positive assessments (line 51), as well as accounts justifying a preference for occasionally drinking tea as provided by Toby himself (lines 17-18, 49). (We take up the issue of collaborative accounting in Flint and Merrison (under review).)

Throughout the extract, then, repetition appears to be closely tied to Toby's attempts to avoid disagreeing with Norma's extended account as to why she prefers drinking tea on occasion. These repetitions are often supported by nodding gestures and various other minimal responses. These all appear to have a similar function - acknowledging the turn, aligning with the activity and accepting the action, but not necessarily providing support. Kangasharju (2002) notes that a repeat is an easily and quickly available device by which interactants can demonstrate alignment with an ongoing activity (here an extended remedial account). Similarly, Curl, Local and Walker (2006) note that repeats are often used in order to demonstrate a collaborative orientation. However, the most relevant description of the function of the repetition observed throughout this extract can be found in Tannen (2007). Tannen considers the interactive functions of repetition and in particular considers repetition as a way of showing listenership $(2007,61)$. At lines 20-21, both interactants use "I think" when talking about how coffee can be dehydrating. This can demonstrate the sharing of a similar stance: saying "I think so" following "I think" could suggest that as both interactants are "thinking" the same thing, that they are once again demonstrating their similarity and solidarity, hence remedying the prior moment of disaffiliation.

The third of the interlinked moves is achieved as Toby accomplishes a gradual movement in stance, from initially displaying a strong preference for coffee over tea, to one in which he affiliates with Norma's stance that tea is preferable at times. At line 17, for instance, Toby joins in with Norma's justification, adding that coffee can be dehydrating, thereby demonstrating an orientation and acceptance of her ongoing justificatory account. Norma acknowledges this contribution through a minimal response (line 19) in a midtelling position, indicating incipient acceptance of Toby's extension of the justificatory account, which follows explicitly in line 21. However, following this, she goes on to continue her own justification (line 23), despite Toby (ostensibly) affiliating with her stance about tea. Norma then goes into further detail regarding hibiscus tea, delivering a fuller account as a remedy to her prior disaffiliation with Toby's initial (preference for coffee) stance. Part of this justification is achieved through Norma mentioning that she drank hibiscus tea while travelling in Egypt. By justifying her reason for initially drinking hibiscus tea, Norma appears to be appealing to moral values in that travel and culture are implicitly invoked as justifications for her tea-drinking habits. Follow- 
ing this, Norma goes on to describe the positive qualities of hibiscus tea, thereby pointing out the benefits of tea-drinking.

Notably, there is a collaborative completion (Lerner 1994) in lines 44-50, as Toby completes the three-part list (Jefferson 1990) initiated by Norma in her description of hibiscus tea. Norma introduces her list at line 44. The first component of the three part structure ("light") is followed by an "and", an accompanying hand shrug, and half a second of silence. As this leaves the turn constructional unit (TCU) hearably incomplete, it provides an opportunity for collaborative completion (see Lerner 1994). However, this isn't taken up by Toby at this opportunity, and Norma provides a second component ("fruity") at line 48. Toby then aligns with the three-part list structure and offers a candidate solution to take the place of the final component (" $r$ - refreshing?=") in line 49. It is worth noting that this candidate completion is offered hesitantly, as evidenced by the restart and rising intonation. Lerner (2004) has suggested that outright rejection rarely occurs in the receipt slot, and this is the case here as at line 50, the candidate is emphatically accepted by Norma (=^yes $\uparrow)$. Given Norma's ready acceptance of Toby's completion of the three-part list, it appears that this joint production is treated by both participants as a vehicle for building affiliation (Ferrara 1992; Hayashi 2013; Lerner 1996).

However, while indicating a preference for drinking tea on occasion, Norma eventually reverts back in lines 66-67 to the initial positive and agreeable stance she proffered in lines 6-8 with respect to drinking coffee. This movement in stance is prefaced, however, with a "yeah but" through which she acknowledges Toby's initial definite preference for coffee, as well as her own preference for coffee being tempered by a preference for tea at certain times. At this point, Toby immediately demonstrates affiliation with the former with an overlapping "yeah" (line 69), and a subsequent increment in line 70, which builds off Norma's unfinished TCU in line 67 , resulting in an ostensibly joint production (i.e. "it's er breakfast of champions").

In sum, in this second extract, we find the two participants carefully interweaving support for the stance of the other in ways that avoid doing outright disaffiliation. The remedial account is accomplished in a manner that allows the two participants to ostensibly affiliate and thus orient to the 'preference for agreeability' in initial interactions. This contrasts with the more striking change in stance following the remedial account in Extract 1, in which a committed Buzzfeed user has (ostensibly) been turned against using Buzzfeed. It is apparent, then, that the extended remedial accounts that follow moments of disaffiliation in initial interactions may prompt either modulations of or, indeed, wholesale changes in prior stances in order to afford the ongoing interactional accomplishment of affiliation in that interaction. 


\section{Conclusion}

In this paper, we have addressed three aims. Firstly, we offered a definition of 'affiliation' which reserves the term for referring only to cases involving affective stance. Secondly, we offered a discussion of the remedial work that follows instances of disaffiliation demonstrating that disaffiliation sequences follow a three-part structure (disaffiliation, extended justification-account and stance movement). Thirdly, we have provided empirical evidence for an earlier proposal that participants orient to the ongoing interactional accomplishment of 'agreeability' in initial interactions.

It has emerged from close analysis that these disaffiliation sequences are treated as interactional troubles that require extensive remedial work in the form of justificatory accounts through which the participants modulate an initially disaffiliative stance. During and subsequent to this remedial work, affiliative responses to the stance accomplished through the remedial account enable participants to modulate that prior momentary disaffiliation, even if that affective stance is not ultimately claimed to be shared. We have also observed that stance movement regularly occurs following this extended account, although the degree of movements in their respective affective stances varied.

In sum, the considerable interactional work involved in these extended remedial account sequences arguably reflects an underlying preference for agreeability in initial interactions (Haugh 2015), at least amongst (Australian and British) speakers of English. It also offers further empirical confirmation of earlier work by McLaughlin, Cody and Rosenstein (1983), in which they claimed that accounts were used as a basis for "reinterpreting disagreeables" (p.107). It also offers a modest contribution to the broader CA project on (dis)affiliation through closely examining what follows instances of disaffiliation between interactants who are getting acquainted, as well as suggesting that accounts recurrently co-occur with disaffiliative responses, a pattern that has not been noted in the case of disagreements with assessments (Pomerantz 1975, 1984). While further work is clearly warranted, it is nevertheless evident that practices by which participants modulate troubles affiliating in initial interactions are torqued to fit the local contingencies of the activity-in-progress, in this case, an overarching preference for agreeability that, in some cases, appears to over-ride the general preference for progressivity in interaction. 


\section{References}

Antaki, Charles. 1994. Explaining and Arguing. London: Sage.

Antaki, Charles. 2012. "Affiliative and Disaffiliative Candidate Understandings." Discourse Studies 14 (5): 531-547. https://doi.org/10.1177/1461445612454074

Arundale, Robert B. 2010. "Constituting Face in Conversation: Face, Facework, and Interactional Achievement.” Journal of Pragmatics 42 (8): 2078-2105. https://doi.org/10.1016/j.pragma.2009.12.021

Atkinson, J. Maxwell, and Paul Drew. 1979. Order in Court: The Organisation of Verbal Interaction in Judicial Settings. London: Macmillan. https://doi.org/10.1007/978-1-349-04057-5

Asmuß, Birte. 2011. "Proposing Shared Knowledge as a Means of Pursuing Agreement." In The Morality of Knowledge in Conversation, ed. by Tanya Stivers, Lorenza Mondada and Jakob Steensig, 207-234. Cambridge: Cambridge University Press. https://doi.org/10.1017/CBO9780511921674.010

Buttny, Richard. 1993. Social Accountability in Communication. Newbury Park: Sage.

Clayman, Steven E. 1992. "Caveat Orator: Audience Disaffiliation in the 1988 Presidential Debates.” Quarterly Journal of Speech 78 (1): 33-6o. https://doi.org/10.1080/00335639209383980

Clift, Rebecca. 2016. “Don’t Make Me Laugh: Responsive Laughter in (Dis)Affiliation.” Journal of Pragmatics 100: 73-88. https://doi.org/10.1016/j.pragma.2016.01.012

Curl, Traci S., John Local, and Gareth Walker. 2006. "Repetition and the Prosody - Pragmatics Interface." Journal of Pragmatics 38 (10): 1721-1751. https://doi.org/10.1016/j.pragma.2006.02.008

Du Bois, John W. 2007. “The Stance Triangle.” In Stancetaking in Discourse: Subjectivity, Evaluation, Interaction, ed. by Robert Englebretson, 139-182. Amsterdam: John Benjamins. https://doi.org/10.1075/pbns.164.07du

Du Bois, John W., and Elise Kärkkäinen. 2012. "Taking a Stance on Emotion: Affect, Sequence, and Intersubjectivity in Dialogic Interaction.” Text \& Talk 32 (4): 433-451. https://doi.org/10.1515/text-2012-0021

Englebretson, Robert. 2007. Stancetaking in Discourse: Subjectivity, Evaluation, Interaction. Amsterdam: John Benjamins. https://doi.org/10.1075/pbns.164

Ferrara, Kathleen. 1992. “The Interactive Achievement of a Sentence: Joint Productions in Therapeutic Discourse." Discourse Processes 15 (2): 207-228. https://doi.org/10.1080/01638539209544809

Flint, Natalie. 2016. "That's What I Thought as Well”: Doing Affiliation in Initial Interactions. Unpublished BA dissertation. York St John University.

Flint, Natalie. 2018. Accounting for Disaffiliations: Remedying (Dis)Affiliations in Initial Interactions between American and British Speakers of English. Unpublished MA dissertation. York St John University.

Flint, Natalie, and Andrew John Merrison. Under review. "On the Collaborative Nature of Accounting: Remedying Potentially Divisive and/or Delicate Topics in Intercultural Initial Interactions."

Goffman, Erving. 1971. "Remedial Interchanges." In Relations in Public: Microstudies of the Public Order, 95-187. Harmondsworth: Pelican. 
Goffman, Erving. 1974. Frame Analysis: An Essay on the Organization of Experience. Cambridge, MA: Harvard University Press.

Goodwin, Charles. 2007. "Participation, Stance and Affect in the Organization of Activities."

Discourse \& Society 18 (1): 53-73. https://doi.org/10.1177/0957926507069457

Goodwin, Charles, and Marjorie Harness Goodwin. 1992. "Assessments and the Construction of Context." In Rethinking Context: Language as an Interactive Phenomenon, ed. by Alessandro Duranti and Charles Goodwin, 147-19o. Cambridge: Cambridge University Press.

Haugh, Michael. 2011. "Humour, Face and Im/politeness in Getting Acquainted." In Situated Politeness, ed. by Bethan L. Davies, Michael Haugh and Andrew John Merrison, 165-184. London: Continuum.

Haugh, Michael. 2012. “Conversational Interaction.” In The Cambridge Handbook of Pragmatics, ed. by Keith Allan and Kasia M. Jaszczolt, 251-274. Cambridge: Cambridge University Press. https://doi.org/10.1017/CBO9781139022453.014

Haugh, Michael. 2015. "Impoliteness and Taking Offence in Initial Interactions." Journal of Pragmatics 86 (1): 36-42. https://doi.org/10.1016/j.pragma.2015.05.018

Haugh, Michael. 2017a. "Mockery and (Non-)Seriousness in Initial Interactions Amongst American and Australian Speakers of English." In Handbook of Communication in CrossCultural Perspective, ed. by Donal Carbaugh, 104-117. Abingdon: Routledge.

Haugh, Michael. 2017b. "Jocular Language Play, Social Action and (Dis)Affiliation in Conversational Interaction." In Multiple Perspectives on Language Play, ed. by Nancy Bell, 143-168. Berlin: Mouton de Gruyter.

Haugh, Michael, and Donal Carbaugh. 2015. "Self-Disclosure in Initial Interactions Amongst Speakers of American and Australian English." Multilingua 34 (4): 461-493. https://doi.org/10.1515/multi-2014-0104

Haugh, Michael, and Danielle Pillet-Shore. 2018. "Getting to Know You: Teasing as an Invitation to Intimacy in Initial Interactions." Discourse Studies 31 (2): 246-269. https://doi.org/10.1177/1461445617734936

Hayashi, Makoto. 2013. “Turn Allocation and Turn Sharing." In The Handbook of Conversation Analysis, ed. by Jack Sidnell and Tanya Stivers, 167-19o. Oxford: John Wiley \& Sons.

Heritage, John. 1984. Garfinkel and Ethnomethodology. Cambridge: Polity Press.

Heritage, John. 1988. “Explanations as Accounts: A Conversation Analytic Perspective.” In Analyzing Lay Explanation: A Case Book of Methods, ed. by Charles Antaki, 127-144. London: Sage.

Holt, Elizabeth. 2012. "Using Laugh Responses to Defuse Complaints." Research on Language and Social Interaction 45 (4): 430-448. https://doi.org/10.1080/08351813.2012.726886

Iwasaki, Shimako. 2015. "Collaboratively Organized Stancetaking in Japanese: Sharing and Negotiating Stance within the Turn Constructional Unit." Journal of Pragmatics 83: 104-119. https://doi.org/10.1016/j.pragma.2015.04.007

Jefferson, Gail. 1984. “On Stepwise Transition from Talk about a Trouble to Inappropriately Next-Positioned Matters.” In Structures of Social Action, ed. by J. Maxwell Atkinson and John Heritage, 191-222. Cambridge: Cambridge University Press.

Jefferson, Gail. 1988. "On the Sequential Organization of Troubles-Talk in Ordinary Conversation.” Social Problems 35 (4): 418-441. https://doi.org/10.2307/800595

Jefferson, Gail. 1990. "List Construction as a Task and Resource", In Interaction Competence, ed. by George Psathas, 63-92. Washington DC: University Press of America. 
Jefferson, Gail. 1993. "Caveat Speaker: Preliminary Notes on Recipient Topic-Shift Implicature." Research on Language and Social Interaction 26 (1): 1-30. https://doi.org/10.1207/s15327973rlsi2601_1

Jefferson, Gail. 2004. "Glossary of Transcript Symbols with an Introduction.” In Conversation Analysis: Studies from the First Generation, ed. by Gene H. Lerner, 13-34. Amsterdam, Philadelphia, PA: John Benjamins Publishing Company. https://doi.org/10.1075/pbns.125.02jef

Jefferson, Gail, Harvey Sacks, and Emanuel A. Schegloff. 1987. "Notes on Laughter in the Pursuit of Intimacy." In Talk and Social Organisation, ed. by Graham Button and John R. E. Lee, 152-205. Clevedon: Multilingual Matters.

Joyce, Jack. 2015. A Partial Sketch of Membership Categorisation Devices in Initial Interactions. Unpublished BA dissertation. York St John University.

Kangasharju, Helena. 2002. "Alignment in Disagreement: Forming Oppositional Alliances in Committee Meetings." Journal of Pragmatics 34 (10): 1447-1471. https://doi.org/10.1016/S0378-2166(02)00073-5

Keevallik, Leelo. 2011. “The Terms of Not Knowing.” In The Morality of Knowledge in Conversation, ed. by Tanya Stivers, Lorenza Mondada and Jakob Steensig, 184-206. Cambridge: Cambridge University Press. https://doi.org/10.1017/CBO9780511921674.009

Kotthoff, Helga. 1993. "Disagreement and Concession in Disputes: On the Context Sensitivity of Preference Structures." Language in Society 22 (2): 193-216. https://doi.org/10.1017/So047404500017103

Lerner, Gene H. 1991. “On the Syntax of Sentences-in-Progress.” Language in Society 20 (3): 441-458. https://doi.org/10.1017/Soo47404500016572

Lerner, Gene H. 1992. "Assisted Storytelling: Deploying Shared Knowledge as a Practical Matter." Qualitative Sociology 15 (3): 247-271. https://doi.org/10.1007/BFoo990328

Lerner, Gene H. 1994. "Responsive List Construction: A Conversational Resource for Accomplishing Multifaceted Social Action." Journal of Language and Social Psychology 13 (1): 20-33. https://doi.org/10.1177/0261927X94131002

Lerner, Gene H. 1996. "Finding "Face" in the Preference Structures of Talk-in-Interaction." Social Psychology Quarterly 59 (4): 303-321. https://doi.org/10.2307/2787073

Lerner, Gene H. 2004. “Collaborative Turn Sequences: Sentence Construction and Social Action.” In Conversation Analysis: Studies from the First Generation, ed. by Gene H. Lerner, 225-256. Amsterdam: John Benjamins. https://doi.org/10.1075/pbns.125.12ler

Levinson, Stephen C. 1983. Pragmatics. Cambridge: Cambridge University Press. https://doi.org/10.1017/CBO9780511813313

Lindström, Anna, and Marja-Leena Sorjonen. 2013. “Affiliation in Conversation.” In The Handbook of Conversation Analysis, ed. by Jack Sidnell and Tanya Stivers, 350-369. Oxford: John Wiley \& Sons.

Maynard, Douglas W., and Don H. Zimmerman. 1984. “Topical Talk, Ritual and the Social Organization of Relationships.” Social Psychology Quarterly 47 (4): 301-316. https://doi.org/10.2307/3033633

McLaughlin, Margaret L., Michael J. Cody, and Nancy E. Rosenstein. 1983. "Account Sequences in Conversations between Strangers." Communication Monographs 50 (2): 102-125. https://doi.org/10.1080/03637758309390157 
Mitchell, Nathaniel, and Michael Haugh. 2015. "Agency, Accountability and Evaluations of Impoliteness." Journal of Politeness Research 11 (2): 207-238.

https://doi.org/10.1515/pr-2015-0009

Nichols, Lawrence. 1990. "Reconceptualizing Social Accounts: An Agenda for Theory Building and Empirical Research." Current Perspectives in Social Theory 10: 113-144.

Ochs, Elinor. 1996. “Linguistic Resources for Socializing Humanity.” In Rethinking Linguistic Relativity, ed. by John J. Gumperz and Stephen C. Levinson, 407-438. Cambridge: Cambridge University Press.

Pillet-Shore, Danielle. 2010. "Making Way and Making Sense: Including Newcomers in Interaction." Social Psychology Quarterly 73 (2): 152-175.

https://doi.org/10.1177/0190272510369668

Pillet-Shore, Danielle. 2011. "Doing Introductions: The Work Involved in Meeting Someone New." Communication Monographs 78 (1): 73-95.

https://doi.org/10.1080/03637751.2010.542767

Pomerantz, Anita. 1975. Second Assessments: A Study of Some Features of Agreements/Disagreements. Unpublished PhD dissertation, University of California, Irvine.

Pomerantz, Anita. 1984. "Agreeing and Disagreeing with Assessments: Some Features of Preferred/Dispreferred Turn Shapes.” In Structures of Social Action, ed. by

J. Maxwell Atkinson and John Heritage, 57-101. Cambridge: Cambridge University Press.

Pomerantz, Anita. 1988. "Offering a Candidate Answer: An Information Seeking Strategy." Communication Monographs 55 (4): 360-373. https://doi.org/10.1080/03637758809376177

Pomerantz, Anita, and John Heritage. (2013) "Preference." In The Handbook of Conversation Analysis, ed. by Jack Sidnell and Tanya Stivers, 210-228. Oxford: John Wiley \& Sons.

Sacks, Harvey. 1987. "On the Preferences for Agreement and Contiguity in Sequences in Conversation." In Talk and Social Organisation, ed. by Graham Button and John R. Lee, 54-69. Clevedon, Avon: Multilingual Matters.

Sacks, Harvey. 1995. Lectures on Conversation. Oxford: Blackwell Publishing. https://doi.org/10.1002/9781444328301

Schegloff, Emanuel A. 1968. "Sequencing in Conversational Openings." American Anthropologist 70 (6): 1075-1095. https://doi.org/10.1525/aa.1968.70.6.02a00030

Schegloff, Emanuel A. 1988. "Goffman and the Analysis of Conversation." In Erving Goffman: Exploring the Interaction Order, ed. by Paul Drew and Anthony Wooton. 89-135. Boston, MA: Northeastern University Press.

Schegloff, Emanuel A. 2007. Sequence Organization in Interaction: A Primer in Conversation Analysis, Volume 1. Cambridge: Cambridge University Press. https://doi.org/10.1017/CBO9780511791208

Schneider, Klaus P. 1988. Small Talk: Analysing Phatic Discourse. Marburg: Hitzeroth.

Schönbach, Peter. 1990. Account Episodes: The Management or Escalation of Conflict. Cambridge: Cambridge University Press.

Scott, Marvin B., and Stanford M. Lyman. 1968. "Accounts." American Sociological Review 33

(1): 46-62. https://doi.org/10.2307/2092239

Semin, Gün R., and Antony S. R. Manstead. 1983. The Accountability of Conduct: A Social Psychological Analysis. London: Academic Press.

Stivers, Tanya. 2008. "Stance, Alignment, and Affiliation during Storytelling: When Nodding is a Token of Affiliation." Research on Language and Social Interaction 41 (1): 31-57. https://doi.org/10.1080/08351810701691123 
Stivers, Tanya. 2010. "An Overview of the Question-Response System in American English Conversation." Journal of Pragmatics 42 (10): 2772-2781.

https://doi.org/10.1016/j.pragma.2010.04.011

Stivers, Tanya, Lorenza Mondada, and Jakob Steensig. 2011. "Knowledge, Morality and Affiliation in Social Interaction." In The Morality of Knowledge in Conversation, ed. by Tanya Stivers, Lorenza Mondada and Jakob Steensig, 3-24. Cambridge: Cambridge University Press. https://doi.org/10.1017/CBO9780511921674.002

Stivers, Tanya, and Jeffrey D. Robinson. 2006. "A Preference for Progressivity in Interaction." Language in Society 35 (3): 367-392. https://doi.org/10.1017/So047404506060179

Stivers, Tanya, and Federico Rossano. 2010. "Mobilizing Response." Research on Language and Social Interaction 43 (1): 3-31. https://doi.org/10.1080/08351810903471258

Stokoe, Elizabeth. 2010. “"Have You been Married, Or...?”: Eliciting and Accounting for Relationship Histories in Speed-Dating Interaction." Research on Language and Social Interaction 43 (3): 260-282. https://doi.org/10.1080/08351813.2010.497988

Svennevig, Jan. 1999. Getting Acquainted in Conversation: A Study of Initial Interactions.

Amsterdam: John Benjamins Publishing.

Svennevig, Jan. 2014. “Direct and Indirect Self-Presentation in First Conversations.” Journal of

Language and Social Psychology 33 (3): 302-327. https://doi.org/10.1177/0261927X13512307

Tannen, Deborah. 2007. Talking Voices: Repetition, Dialogue, and Imagery in Conversational

Discourse. Cambridge: Cambridge University Press.

https://doi.org/10.1017/CBO9780511618987

\title{
Appendix Additional transcription conventions
}

[ $\quad]^{1}$ Superscript numbers are used where necessary to indicate what talk/action is in overlap with what other talk/action(s).

((nods)) Gesture is transcribed in italics, within double round brackets and on a dedicated gesture line in order to see when a gesture starts and begins in relation to the talk.

$\% \quad$ Talk which shows participant "putting on a voice".

\section{Address for correspondence}

\author{
Natalie Flint \\ Ulster University \\ School of Communication and Media \\ Shore Road, Newtownabbey \\ BT37 OQB \\ United Kingdom \\ flint-n@ulster.ac.uk
}




\section{Biographical notes}

Natalie Flint is a PhD Researcher in the School of Communication and Media at Ulster University. Her research uses conversation analysis to investigate interpersonal aspects of talkin-interaction, primarily issues of remedying conflict and disagreement. Having worked on university seminar discussions and initial interactions, her $\mathrm{PhD}$ focuses on family data.

(iD) https://orcid.org/o0oo-0002-2085-9125

Michael Haugh is Professor of Linguistics in the School of Languages and Cultures, University of Queensland. His research interests lie in pragmatics, conversation analysis and intercultural communication, with a particular focus on the role of language in social interaction.

Andrew Merrison's research concerns the socio-pragmatics of inter-action. Influenced by Goffman and Sacks, he has worked on: students' e-mail apologies, requests and complaints to university faculty; face and identity issues online; interpreted sign language interactions; and repair in speech and language therapy. His favourite words are still minimum and outwith.

\section{Publication history}

Date received: 9 May 2017

Date accepted: 16 January 2019

Published online: 26 June 2019 